\title{
ETIKA KERJA ISLAM DAN KEADILAN ORGANISASI: Studi Pada BMT di Kabupaten Kudus
}

\author{
Wahibur Rokhman \\ STAIN Kudus, Jawa Tengah Indonesia \\ Wahibur@gmail.com
}

\begin{abstract}
WORK ETHICS OF ISLAM AND ORGANIZATIONAL JUSTICE: Study on a BMT in Kudus, This research aims to analyze the relationship of work ethics of Islam and organizational justice in BMT in Kudus. The organizational justice is measured using three dimensions of justice developed by Cropanzano et al. (2007), they are: distribution justice, procedural fairness and interactional justice. Further, the study also tested the influence of the three dimensions of justice against work ethics of Islam felt by employees. The results of this research show that the level of organizational justice and work ethics of Islam felt by employees working in the BMT in Holy is high enough. The results of the regression analysis also showed a significant positive influence on the distribution of Justice, procedural fairness and interactional justice against the work ethics of Islam. Implications, limitations and suggestions for the next research are also discussed in this article.
\end{abstract}

Keywords: Distribution Justice, Procedural Justice, Work Ethics Of Islam. 


\begin{abstract}
Abstrak
Penelitian ini bertujuan untuk menganalisis bubungan etika kerja Islam dan keadilan organisasi di Baitul mal wat tamwil (BMT) di Kabupaten Kudus. Keadilan Organisasi disini diukur menggunakan tiga dimensi keadilan yang dikembangkan oleh Cropanzano dkk. (2007) yaitu: keadilan distribusi, keadilan prosedural dan keadilan interaksional. Lebih lanjut, penelitian ini juga menguji pengaruh tiga dimensi keadilan terhadap etika kerja Islam yang dirasakan oleh karyawan. Hasilpenelitian ini menunjukkan bahwa tingkeat keadilan organisasi dan etika kerja Islam yang dirasakan oleh karyawan yang bekerja di BMT di Kudus cukup tinggi. Hasil analisis regresi juga menunjukkan adanya pengaruh yang positif signifikan keadilan distribusi, keadilan prosedural dan keadilan interaksional terhadap etika kerja Islam. Implikasi, keterbatasan dan saran untuk penelitian yang akan datang juga dibahas dalam artikel ini.
\end{abstract}

Kata Kunci: Keadilan Distribusi, Keadilan Prosedural, Etika Kerja Islam.

\title{
A. Pendahuluan
}

Runtuhnya korporasi besar seperti Enron, Arthur Anderson, Worldcom, Global Crossing karena mega skandal menjadikan etika kerja mendapat perhatian yang sangat besar di dunia bisnis. Hal ini menunjukkan bahwa sehebat dan seprofesional apapun pengelolaan perusahaan jika tidak dilandasi dengan etika kerja yang baik maka akan terjadi manipulasi yang berakibat pada kebangkrutan. Sehingga sekarang ini sekolahsekolah ternama dalam bidang bisnis seperti: Harvard Business School (HBS) dan London Business School (LBS) memasukkan mata kuliah etika kerja di dalam kurikulumnya. ${ }^{1}$

Tidak seperti etika kerja Kristen, etika kerja Islam telah disalah pahami dan dilupakan dalam kajian ilmu organisasi dan manajemen bisnis. Ini disebabkan para ahli manajemen tidak menggali kekayaan literatur Islam yang terkait dengan bisnis dan

${ }^{1}$ Abeng, $T$ "Business ethics in Islamic context: perspectives of a Muslim business leader" dalam Journal of Business Ethics Quarterly Vol. 7 No. 3, 1997, hlm. 47-54. 
organisasi. ${ }^{2}$ Literatur dan penelitian etika kerja yang berkembang sekarang masih dominasi peneliti-peneliti barat yang notabene berdasarkan pada etika Kristen Protestan. ${ }^{3}$ Konsep etika kerja Protestan pertama di kembangkan oleh Max Weber dalam buku yang berjudul The Protestant Ethic and the Spirit of Capitalism, yang mengaitkan antara kesuksesan sistem kapitalis dengan ajaran Protestan.

Islam sebagai agama yang mengatur segala aspek kehidupan manusia, memiliki konsep yang mengatur tentang etika dalam bekerja yang berdasarkan pada Alqur'an dan Hadist. Namun belum banyak dilakukan penelitian tentang etika kerja Islam, sehingga konsep etika kerja Islam kurang berkembang. Hanya ada beberapa riset tentang etika kerja Islam seperti Ali pada tahun 1988, Yousef pada tahun 2000, 2001, Rahman, Muhamad, dan Othman pada tahun 2006, Ali dan Al-Kazemi pada tahun 2007 dan Khalil dan Abu-Saad pada tahun 2009. ${ }^{4}$

Penelitian etika kerja banyak dikaitkan dengan rasa keadilan dalam organisasi. Penelitian sebelumnya menunjukkan adanya hubungan yang erat antara keadilan organisasi dengan etika kerja. Misalnya, Grenberg pada tahun 1993 menemukan bahwa karyawan yang merasa diperlakukan tidak adil maka berusaha untuk mengambil asset perusahaan sebagai usaha untuk menyeimbangkan perlakuan ketidakadilan distribusi sumberdaya yang mereka terima. Lebih lanjut, Trevino dan weaver pada tahun 2001 menemukan bahwa ketidakadilan yang dirasakan oleh karyawan akan menimbulkan keinginan karyawan untuk mencari

${ }^{2}$ Ali, A. "Scaling an Islamic work ethic" dalam Journal of Social Psychology, Vol. 5, 1988, hlm. 575-583.

${ }^{3}$ Yousef, D. A. "Organisational commitment as a mediator of the relationship between Islamic work ethic and attitudes toward organisational change" dalam Journal of Human Relations, Vol. 53, No. 4, 2000, hlm.13-37.

${ }^{4}$ Khalil dan Abu-Saad "Islamic work ethic among arab college students in Israel” dalam Cross Cultural Management: An International Journal Vol. 16 No. 4, 2009, hlm. 333-346. 
kesempatan untuk meningkatkan kesejahteraan mereka sendiri, meskipun mereka nilai tidak etis tetapi tetap mereka lakukan.

Melihat kenyataan dilapangan dan riset-riset sebelumnya, penelitian ini mencoba mengembangkan penelitian sebelumnya, dengan menguji tingkat keadilan organisasi dan etika kerja Islam yang dimiliki para karyawan yang bekerja pada lembaga keuangan mikro berbasis syari'ah yaitu BMT. Dengan tujuan dapat memberi gambaran tentang tingkat keadilan kerja dan etika kerja Islam di BMT. Disini keadilan organisasi akan menggunakan tiga dimensi keadilan yaitu: keadilan distribusi, keadilan prosedur dan keadilan interaksional. Lebih lanjut, penelitian ini juga menguji pengaruh tiga dimensi keadilan organisasi terhadap etika kerja Islam dalam kontek Baitul mal wat tamwil (BMT) di Kabupaten Kudus.

\section{B. Pembahasan}

\section{Etika Kerja Islam}

Konsep etika kerja Islam merupakan bentuk respons dari para pakar muslim dibidang teori organisasi dan sumberdaya manusia atas konsep etika kerja Protestan yang dicetuskan oleh Max Weber. Konsep ini juga mengkonter pendapat Weber tentang masyarakat Muslim yang tidak maju dibidang ekonomi karena berbagai alasan yang menyudutkan umat Islam seperti sufisme, sikap fatalistic dan outokratik pada kerajaan-kerajaan Islam.

Berbagai penelitian telah dilakukan untuk mengkonter pendapat Weber, seperti yang dilakukan oleh Arslan pada tahun 2000 yang membandingkan etika kerja para manajer di Inggris dan Turki menggunakan instrument Protestant work ethics. Hasilnya menunjukkan bahwa para manajer di Turki memiliki karakteristik etika kerja lebih tinggi dibandingkan para manager di Inggris. Dalam kesimpulan penelitiannya, Arslan menjelaskan bahwa penelitiannya akan memberi dampak sebagai berikut: 
a. Bahwa kritik Weber terhadap sikap orang muslim terhadap perilaku ekonomi tidak benar, khususnya di Turki.

b. Bahwa agama Islam merupakan motivator penting dan memiliki efek yang sangat besar pada bisnis orang Islam.

c. Gerakan sufi di Turki memiliki peran yang sama dengan peran gerakan Kristen "Calvinism" di Eropa Utara di abad 18 dan etika dan sejarah Islam memiliki peran penting dalam etika bisnis.

Lebih lanjut, Ali pada tahun 1988 mengembangkan instrument yang digunakan untuk mengukur etika kerja Islam dan perilaku individu. Beliau menggunakan 150 mahasiswa arab yang sedang belajar di Amerika. Kemudian pada tahun 2001, beliau menguji skala yang dibuat pada 117 manajer di Arab Saudi. Hasilnya menunjukkan bahwa manajer yang memiliki komitmen terhadap etika kerja Islam tinggi akan cenderung memiliki tendensi yang moderat terhadap sikap individualisme.

Yousef pada tahun 2000 meneliti peran etika kerja Islam sebagai memediasi hubungan antara locus of control, peran dalam perselisihan (role conflict) dan peran dalam keraguan (role ambiguity). Hasilnya menunjukkan bahwa etika kerja Islam terkait dengan locus of control, dan etika kerja Islam memediasi hubungan antara locus of control dan role ambiguity. Penelitian lanjutan juga di lakukan oleh Yousef pada tahun 2001, dia menguji hubungan antara etika kerja Islam dan komitmen organisasi serta kepuasan kerja. Penelitian ini dilakukan di Uni Emirat Arab dengan sampel 425 karyawan yang bekerja di berbagai perusahaan. Hasilnya menunjukkan bahwa etika kerja Islam berpengaruh langsung terhadap komitmen organisasi dan kepuasan bawahan, serta etika kerja Islam memediasi hubungan antara komitmen organisasi dan kepuasan kerja. ${ }^{5}$

${ }^{5}$ Yousef, D. A. "Organisational commitment as a mediator of the relationship between Islamic work ethic and attitudes toward organisational change" dalam Journal of Human Relations, Vol. 53, No. 4, 2000, hlm.37-40. 
Penelitian tentang etika kerja Islam juga telah dilakukan di Malaysia, Rahman pada tahun 2006 meneliti hubungan antara etika kerja Islam dengan komitmen organisasi. Mereka menggunakan tiga dimensi komitmen organisasi yaitu affective, normative dan continuance. Penelitian ini menggunakan sampel sebanyak 227 karyawan yang bekerja di berbagai bank di Malaysia. Hasilnya menunjukkan bahwa etika kerja Islam memeliki efek yang positif pada ketiga dimensi yang ada di komitmen organisasi, lebih lanjut komitmen affective memiliki hubungan yang lebih besar daripada komitmen normative dan continuance.

\section{Keadilan Organisasi}

Keadilan merupakan konsep yang sangat penting dalam berbagai pendekatan dalam ilmu sosial. ${ }^{6}$ Dalam kontek organisasi, konsep keadilan terkait dengan keadilan terhadap pembagian sumberdaya organisasi yang dimulai dari proses seleksi, penggajian, promosi, penilaian dan lainnya. Menurut Cropanzano ada tiga dimensi dalam keadilan organisasi yaitu: keadilan distribusi, keadilan posedural dan keadilan interaksional. ${ }^{7}$

Konsep awal dari teori keadilan berdasar konsep pembagian sumberdaya yang adil dalam organisasi yang biasanya disebut keadilan distributif (distributive justice). Keadilan ini berdasar pada teori ikuitas. ${ }^{8}$ Teori ini menjelaskan bahwa perilaku karyawan merupakan hasil dari keseimbangan antara beban kerja dan manfaat yang diperoleh dari organisasi. Setiap individu dalam organisasi akan mengukur dan membandingkan antara konstribusi yang diberikan pada organisasi dan feedback yang mereka peroleh. Ada tiga faham yang digunakan dalam penilaian keadilan distribusi yaitu: pertama, ekuitas (equity), penilaian ini berdasarkan

${ }^{6}$ Colquitt, J. A., Greenberg, J. dan Zapata-Phelan, "What is Organizational Justice?. A historical overview". dalam Handbook of Organizational Justice, LEA Publisher, Mahwah. NJ, 2005, hlm. 13-56.

${ }^{7}$ Cropanzano, R., Bowen, D. E. dan Gilliland, S. W. "The management of organizational justice” dalam Academy of Management Perspectives, Vol. 21, 2007, hlm 34-48.

${ }^{8}$ Ibid., hlm.50. 
pada pendapat bahwa hasil yang diperoleh seseorang hendaknya berdasar pada konstribusi yang diberikan seseorang terhadap organisasi, semakin besar kontribusi yang diberikan, semakin banyak reward yang harus di dapat. ${ }^{9}$ Kedua, kesetaraan (equality), faham ini berpendapat bahwa keadilan tercipta bilamana karyawan mendapat kompensasi yang sama, tanpa memandang seberapa kontribusi yang mereka berikan pada organisasi. Yang terakhir yaitu kebutuhan (need), faham ini berpendapat bahwa pemberian kompensasi hendaknya berdasarkan kebutuhan karyawan, tidak berdasarkan kontribusi atau kesetaraan. Karyawan yang memiliki kebutuhan lebih banyak, dia yang memperoleh kompensasi yang lebih banyak.

Selanjutnya, penelitian tentang keadilan organisai bergeser dari penekanan pada berapa kompensasi yang mereka peroleh, menuju penekanan pada bagaimana prosedur pembagian sumber daya itu dilakukan, yang biasa disebut keadilan prosedur (procedural justice). Penelitian yang dilakukan oleh Thibaut dan Walker ${ }^{10}$ menemukan bahwa karyawan yang menerima hasil kurang baik dari organisasi maka mereka akan mengevaluasi cara pembagian dan penentuan hasil tersebut, sikap positif akan muncul jika mereka percaya bahwa proses untuk menentukan hasil tersebut dilakukan secara adil. ${ }^{11}$ Leventhal mengidentifikasi ada enam aturan yang digunakan dalam keadilan prosedural yaitu: ${ }^{12}$

1. Konsistensi (consistency): prosedur hendaknya konsisten di terapkan tanpa memandang orang dan waktu.

2. Akurasi (acuracy): prosedur hendaknya berdasarkan informasi yang akurat.

${ }^{9}$ Ibid., hlm. 21.

10 Thibaut, J. dan Walker, L. "Procedural Justice: A Psychological Analysis" dalam Hillsdale, NJ: Lawrence Erlbaum Associates, 1975, hlm. 42.

${ }^{11}$ Schminke, M., Ambrose, M. dan Noel, T. "The effect of ethical frameworks on perceptions of organizational justice" dalam Academy of Management Journal, Vol. 40, No. 5, 1997, hlm. 1190-1207.

${ }^{12}$ Leventhal, GS. "The distribution of rewards and resources in groups and organizations" dalam L. Berkowitz and E. Walster (Eds.), Advances in Experimental Social Psychology, Vol. 9, 1980, hlm. 91-131. 
3. Tidak Bias (unbias): prosedur hendaknya tidak bias dengan kepentingan pribadi dan tuduhan yang tak berdasar fakta.

4. Bisa diperbaiki (correctable): prosedur hendaknya memiliki kemungkinan untuk diperbaiki dan dimodifikasi

5. Keterwakilan (representativeness): prosedur hendaknya mencerminkan keterwakilan setiap kelompok atau golongan dalam organisasi.

6. Beretika (ethicality): prosedur hendaknya mengikuti nilainilai etika yang dianut oleh anggota organisasi.

Konsep ketiga dari keadilan organisasi yaitu keadilan interaksional. Konsep ini berdasar pada teori pertukaran sosial dan norma timbal balik. ${ }^{13}$ Berdasarkan perpektif teori pertukaran sosial (social exchange theory), bahwa setiap karyawan berharap dapat diperlakukan organisasi secara terhormat, jujur, sopan dan adil dalam berbagai proses pertukaran dalam organisasi. Sedangkan dalam perpektif teori norma timbal balik (norm of reciprocity theory), bahwa karyawan yang diperlakukan secara positif oleh organisasi akan memberikan feedback positif dengan meningkatkan komitmennya pada nilai-nilai dan tujuan organisasi, yang pada akhirnya berpengaruh pada peningkatan kontribusinya pada organisasi. ${ }^{14}$

Lebih lanjut, keadilan interaksional juga terkait dengan persepsi karyawan tentang implementasi keadilan distribusi dan keadilan prosedural, yaitu dengan cara memberi penjelasan tentang kebijakan yang diambil dengan baik dan sopan. ${ }^{15}$ Bies dan Moag berpendapat bahwa persepsi tentang keadilan

${ }^{13}$ Cropanzano, R., DE. Bowen and SW. Gilliland. "The management of organizational justice" dalam Academy of Management Perspectives Vol. 21, 2007, hlm. 34-48

${ }^{14}$ Rizk, R. R. "Back to basics: an Islamic perspective on business and work ethics", dalam Social Responsibility Journal, Vol. 1, No. 2, 2008, hlm. 246254.

${ }^{15}$ Cropanzano, R. dan J. Greenberg. "Progress in organizational justice: tunneling through the maze dalam International Review of Industrial and Organizational Psychology, Vol. 12, 1997, hlm. 317-72 
interaksional dipengaruhi oleh berbagai faktor diluar prosedur formal. ${ }^{16}$ Perlakuan interpersonal yang diterima karyawan pada waktu implementasi prosedur akan berpengaruh pada persepsi terhadap keadilan organisasi secara keseluruhan Persepsi yang positif akan muncul jika individu diperlakukan secara ramah dan hormat. ${ }^{17}$

\section{Keadilan Organisasi dan Etika Kerja Islam}

Penelitian yang menghubungkan keadilan organisasi dan etika kerja Islam kurang mendapat perhatian oleh para ahli. ${ }^{18}$ Ada berbagai penelitian yang menguji hubungan antara etika dan keadilan kerja. Grenberg menemukan bahwa karyawan yang merasa diperlakukan tidak adil maka berusaha untuk mengambil asset perusahaan sebagai usaha untuk menyeimbangkan perlakuan ketidakadilan distribusi sumberdaya yang mereka terima. ${ }^{19}$ Lebih lanjut, Trevino dan Weaver menemukan bahwa ketidakadilan yang dirasakan oleh karyawan akan menimbulkan keinginan karyawan untuk mencari kesempatan untuk meningkatkan kesejahteraan mereka sendiri, meskipun mereka nilai tidak etis tetapi tetap mereka lakukan. ${ }^{20}$ Berdasarkan fakta ini, maka muncul hipotesis:

a. H1: Keadilan distribusi berpengaruh positif terhadap etika kerja Islam

b. H2. : Keadilan prosedural berpengaruh positif terhadap etika kerja Islam

${ }^{16}$ Ibid., hlm. 75.

${ }^{17}$ Ibid., hlm. 52.

${ }^{18}$ Colquitt, J. A., Greenberg, J. dan Zapata-Phelan, "What is Organizational Justice?. A historical overview" Handbook of Organizational Justice. LEA Publisher, Mahwah. NJ, 2005, hlm. 3-56.

${ }^{19}$ Greenberg, J.. "Justice in the Workplace: Approaching Fairness in Human Resource Management" dalam R. Cropanzano (Eds.), The Social Side of Fairness:Interpersonal and Informational Classes of Organizational Justice. Hillsdale, NJ: Lawrence Erlbaum Associates, 1993, hlm. 14.

${ }^{20}$ Tre Trevino, L. dan Weaver, G. "Organizational Justice and ethic program "follow-trough": influences on employees' harmful and helpful behavior" Journal of Business Ethics Quarterly, Vol. 11, No. 4, 2001, hlm. 651-657. 
c. H3. : Keadilan Interaksional berpengaruh positif terhadap etika kerja Islam.

\section{Sampel Penelitian}

Sampel dalam penelitian ini adalah karyawan yang bekerja di Baitul Mal wat Tamwil (BMT) di kabupaten Kudus. Penelitian ini menggunakan tehnik purposive sampling. Tehnik ini digunakan dengan cara menentukan kreteria tertentu yang digunakan untuk menentukan kelayakan anggota populasi menjadi sampel penelitian. Dalam penelitian ini menggunkan kreteria: karyawan yang menjadi sampel dalam penelitian ini minimal telah bekerja selama 1 tahun di BMT, supaya dapat merasakan tentang keadilan dan etika kerja Islam yang dipraktekkan dalam organisasi.

Responden dalam penelitian ini adalah karyawan yang bekerja sebagai karyawan tetap pada BMT di Kabupaten Kudus. Kuesioner yang disebarkan sebanyak 150 buah, namun yang kembali sebanyak 135 buah dengan response rate sebesar $90 \%$. Namun dari kuesiner yang dikembalikan sebanyak 9 buah yang tidak dapat dipakai dalam analisis lanjutan karena banyaknya item yang tidak terisi dan ada empat responden yang bekerja kurang dari satu tahun, sehingga tidak memenuhi sarat sebagai sampel dalam penelitian ini. Sehingga total jawaban responden yang bisa dipakai sebanyak 126 buah. Berikut ini gambaran secara umum tentang responden terkait dengan jenis kelamin, pendidikan, usia maupun pengalaman kerja:

Tabel 1. Karakterisik Responden

\begin{tabular}{lcc}
\hline Keterangan & Frequency & Percentage \\
\hline Jenis Kelamin & & \\
Laki-Laki & 64 & $51 \%$ \\
Perempuan & 62 & $49 \%$ \\
Total & $\mathbf{1 2 6}$ & $\mathbf{1 0 0} \%$ \\
\hline
\end{tabular}


Etika Kerja Islam Dan Keadilan Organisasi

\begin{tabular}{lcc}
\hline Umur & & \\
$\geq 25$ & 42 & $33 \%$ \\
$26-30$ & 53 & $42 \%$ \\
$31-34$ & 17 & $13,5 \%$ \\
$35 \leq$ & 14 & $11,5 \%$ \\
Total & 126 & $\mathbf{1 0 0} \%$ \\
\hline Tingkat Pendidikan & & \\
SLTA & 39 & $30 \%$ \\
Diploma & 35 & $28 \%$ \\
Sarjana & 50 & $40 \%$ \\
Pasca Sarjana & 2 & $2 \%$ \\
Total & 126 & $\mathbf{1 0 0} \%$ \\
\hline Pengalaman Bekerja & & \\
(Tahun) & & $36 \%$ \\
$1-2$ & 46 & $28 \%$ \\
$3-4$ & 35 & $21 \%$ \\
$5-6$ & 27 & $13 \%$ \\
$7-9$ & 16 & $2 \%$ \\
$10-$ keatas & 2 & $\mathbf{1 0 0 \%}$ \\
Total & $\mathbf{1 2 6}$ & \\
\hline
\end{tabular}

\section{Pengukuran Variabel}

Variabel etika kerja Islam diukur menggunakan 17 item pertanyaan yang telah dikembangkan oleh Ali (1988) kemudian diperbaiki Ali dan Azim (1999) dan Ali dan Al-Kanzemi (2002). Instrumen menggunakan 5 skala likert dengan reliabilitas konsistensi Crombach Alpha sebesar 0.85. Variabel Keadilan organisasi diukur menggunakan 13 item pertanyaan yang dikembangkan oleh Niehoff dan Moorman (1993) dan Folger dan Konovsky (1989). Instrumen menggunakan 5 skala likert. Skala ini dilaporkan memiliki reliabilitas cronbach alpa diatas 0.90 .

\section{Analisis Data}

Analisis data dilakukan dengan bantuan aplikasi program SPSS18.00. Analsis ini meliputi analisis diskriptif meliputi frekuensi dan prosentase dari sampel. Untuk menguji hipotesis, penelitian ini menggunakan regresi yang menguji pengaruh keadilan organisasi terhadap etika kerja Islam. 
Tabel 2 melaporkan hasil analisis statistic diskriptif meliputi mean, standar diviasi dan korelasi antar variabel. Dari hasil ini dapat kita lihat rata-rata jawaban dari responden menunjukkan bahwa persepsi karyawan BMT terhadap pembagian sumberdaya dan pemberian gaji mereka anggap cukup adil dengan nilai ratarata 3,84. Dari hasil diatas menunjukkan bahwa persepsi karyawan terhadap keadilan dalam prosedur penentuan gaji dan pembagian sumberdaya organisasi dianggap sudah adil ini ditunjukkan dengan sedangkan nilai rata dari keseluruhan instrument 3.78. Nilai ini menunjukkan bahwa persepsi karyawan terhadap keadilan dalam berinteraksi antar karyawan dan manajer dianggap sudah adil . Sedangkan nilai rata-rata secara keseluruhan sebesar 3,96, hal ini menunjukkan bahwa tingkat etika kerja islam yang diterapkan dan dirasakan oleh karyawan di BMT kabupaten kudus cukup tinggi yaitu mendekati angka 4 dari skala 5 poin.

Lebih lanjut, tabel dua juga menjelaskan hubungan antara keadilan distribusi dengan etika kerja Islam adalah positif signifikan $(\mathrm{r}=0.254 ; \mathrm{p}<0.01)$ dan juga hubungan antara keadilan prosedural dengan etika kerja Islam juga positif signifikan ( $\mathrm{r}=.471 ; \mathrm{p}<0.01)$, begitu juga hubungan antara keadilan interaksional $(\mathrm{r}=0.251 ; \mathrm{p}<0.01)$. Namun demikian, hasil uji korelasi menunjukkan hasil yang tidak signifikan hubungan antara keadilan distribusi dengan keadilan prosedural serta keadilan prosedural dengan keadilan interaksional.

Tabel II Mean, Standar Deviasi, Korelasi Antar Variabel

\begin{tabular}{ccccccc}
\hline No & Variables & Mean & SD & $\mathbf{2}$ & $\mathbf{3}$ & 4 \\
\hline 1 & Keadilan Distribusi & 3,84 & .58 & 0.04 & $.245^{* *}$ & $.254^{* *}$ \\
\hline 2 & Keadilan Prosedural & 3,51 & .95 & & 0.08 & $.471^{* *}$ \\
\hline 3 & Keadilan Interaksional & 4,30 & .71 & & & $.251^{* *}$ \\
\hline 4 & Etika Kerja Islam & 3,94 & .34 & & & \\
\hline & $* \mathrm{p}<.05$ & & & & & \\
& $* *_{\mathrm{p}}<.01$ & & & & &
\end{tabular}

Hasil uji regresi di tunjukkan pada tabel III berikut ini: 
Etika Kerja Islam Dan Keadilan Organisasi

Tabel III. Hasil Analisis Regresi

\begin{tabular}{ccccc}
\hline & & \multicolumn{3}{c}{ Variabel dependen Etika Kerja Islam } \\
\cline { 3 - 4 } & Variables & $\beta$ & $\mathrm{t}$ & $\mathrm{R}^{2}$ \\
\hline Independent Variable & & & \\
$\bullet$ & Keadilan Distributif & $.186^{* *}$ & $2.99^{* *}$ & \\
$\bullet \quad$ Keadilan Prosedural & $.462^{* *}$ & $5.95^{* *}$ & $.316^{* *}$ \\
& Keadilan & $.202^{* *}$ & $2.88^{* *}$ & \\
\hline
\end{tabular}

Note: ${ }^{*} \mathrm{p}<0.05,{ }^{* *} \mathrm{p}<0.01$

Dari hasil tabel diatas dapat kita lihat bahwa nilai t sebesar 2.99 dengan tingkat signifikansi dibawah 0.01, dengan demikian maka Ho ditolak dan Ha diterima. Hal ini menunjukkan bahwa hipotesis pertama terbukti dan dapat diterima. Dengan nilai koefisien beta yang positif ini menunjukkan bahwa keadilan distribusi memeliki efek yang positif terhadap penggunaan etika kerja Islam. Dengan perkataan lain, semakin karyawan karyawan diperlakukan secara adil dalam pembagian sumberdaya yang ada dalam organisasi maka semakin memotivasi karyawan untuk mengamalkan etika kerja Islam dalam organisasi.

Hasil uji t pada tabel diatas menunjukkan bahwa nilai $\mathrm{t}$ sebesar 5.95 dengan tingkat signifikansi dibawah 0.01. Hal ini menunjukkan bahwa hipotesis kedua terbukti dan dapat diterima, dengan menolak Ho dan Ha diterima. Dengan nilai koefisien beta yang positif ini menunjukkan bahwa keadilan prosedural memiliki efek yang positif terhadap penggunaan etika kerja Islam. Dengan perkataan lain, semakin karyawan karyawan diperlakukan secara adil dalam prosedur penentuan dan pembagian sumberdaya yang ada dalam organisasi maka semakin memotivasi karyawan untuk mengamalkan etika kerja Islam dalam organisasi.

Hasil uji t pada tabel diatas menunjukkan bahwa nilai $\mathrm{t}$ sebesar 2,888 dengan tingkat signifikansi dibawah 0.01,. Hal ini menunjukkan bahwa hipotesis ketiga terbukti dan dapat diterima, dengan menolak Ho dan Ha diterima. Dengan nilai koefisien beta yang positif ini menunjukkan bahwa keadilan interaksional 
memiliki efek yang positif terhadap penggunaan etika kerja Islam. Dengan perkataan lain, semakin karyawan karyawan diperlakukan secara adil dalam berhubungan sosial yang ada dalam organisasi maka semakin memotivasi karyawan untuk mengamalkan etika kerja Islam dalam organisasi.

Selanjutnya, dari hasil perhitungan diatas dapat diketahui bahwa koefisien determinasi $\left(\mathrm{R}^{2}\right)$ yang diperoleh sebesar 0.316 . Hasil ini berarti bahwa variabel keadilan distribusi, keadilan prosedural dan keadilan interaksional dapat menjelaskan variabel etika kerja Islam sebesar 31,6\%, sedangkan sisanya 68,4\% dijelaskan oleh variabel lain.

\section{Hasil analisa data}

Dari hasil analisis deskriptif secara umum variabel pada penelitian ini mendapatkan penilaian dari responden cukup baik. Hal ini dapat ditunjukkan dari tanggapan persetujuan yang tinggi dari responden terhadap setiap variabel yang diteliti. Dari hasil tersebut diperoleh kesimpulan bahwa ada pengaruh positif dari keadilan distribusi, keadilan prosedural dan keadilan interaksional terhadap etika kerja islam pada karyawan BMT di Kabupaten Kudus.

Pengujian hipotesis pertama menunjukkan adanya pengaruh yang positif dan signifikan variabel keadilan distributif pada etika kerja islam. Hasil ini menunjukkan bahwa pembagian sumberdaya yang adil dalam organisasi sangat berpengaruh terhadap penerapan etika Islam dalam perusahaan. Penelitian ini sejalan dengan penelitian yang dilakukan oleh Greenberg (1993), yang menemukan bahwa karyawan yang diperlakukan tidak adil oleh orgnaisasi akan melakukan tidakan untuk memperoleh haknya meskipun dinilai tidak etis. Tindakan yang tidak etis ini dilakukan karena ingin menyeimbangkan antara kontribusi yang karyawan berikan pada perusahaan dan apa yang mereka peroleh sehingga terjadi keseimbangan. 
Penggunaan prosedur yang tepat dalam penentuan pembagian sumberdaya dalam organisasi sangat berpengaruh terhadap perilaku etis karyawan dalam perusahaan. Hasil penelitian ini menunjukkan bahwa ada pengaruh yang positif signifikan keadilan prosedural terhadap etika kerja Islam, sehingga hipotesis ke dua di dukung. Penelitian ini mendapat dukungan dari penelitian sebelumnya yang dilakukan Cropazano dan Stein (2009) yang menemukan keterkaitan antara dimensi keadilan organisasi dengan etika kerja.

Hasil pengujian hipotesis tiga mendapatkan bahwa keadilan interaksional sangat berpengaruh terhadap etika kerja Islam. Hal ini berarti semakin karyawan diperlakukan secara adil dalam berbagai hubungan sosial dalam organisasi maka karyawan akan menjunjung tinggi etika. Penelitian ini juga sesuai dengan penelitian Cropazano dan Stein (2009) yang menemukan keterkaitan antara dimensi keadilan organisasi dengan etika kerja.

\section{Simpulan}

Dari hasil analisis diatas kesimpulan dari penelitian ini adalah: pertama, berdasarkan analisis statistik diskriptif, hasil penelitian ini menunjukkan bahwa persepsi karyawan BMT terhadap keadilan organisasi cukup tinggi. Hal ini dapat dilihat dari rata-rata dari tiga dimensi keadilan organisasi mendekati angka 4 dari 5 skala pengukuran. Karyawan BMT di kudus merasakan diperlakukan secara adil baik dalam distribusi sumberdaya, prosedur penentuannya maupun keadilan dalam berinteraksi. Lebih lanjut, Berdasarkan hasil analisis data etika kerja Islam, dapat dilihat bahwa tingkat etika kerja Islam cukup tinggi, hal ini dapat dilihat dari rata-rata 3,9. Dari hasil ini dapat disimpulkan bahwa persepsi karyawan BMT terhadap keadilan organisasi dan Etika kerja Islam cukup tinggi.

Selanjutnya, berdasarkan analisis secara parsial menunjukkan bahwa semua dimensi keadilan organisasi baik 
keadilan distributif, prosedural maupun interaksional mempunyai pengaruh positif signifikan terhadap etika kerja. Hal ini dapat disimpulkan bahwa karyawan akan bersikap etis jika diperlakukan secara adil baik dari sisi distribusi, prosedural maupun interaksional. Ketiga, berdasarkan pengujian secara simultan, ternyata penelitian ini membuktikan bahwa secara bersamasama variabel independen (keadilan distributif, prosedural dan interaksional) mempunyai pengaruh positif signifikan terhadap variabel dependen yaitu etika kerja Islam.

Berdasarkan hasil analisis, penelitian ini memiliki dua implikasi yaitu implikasi teoritis maupun implikasi praktis. Adapun implikasi teoritis dari penelitian ini adalah bahwa keadilan distributif, prosedural dan interaksional memiliki pengaruh positif terhadap etika kerja Islam. Hasil penelitian ini juga memperkuat penelitian sebelumnya yang dilakukan oleh Trevino dan Weaver (2001) yang menemukan adanya pengaruh keadilan distribusi pada etika. Hasil penelitian ini sejalan dengan penelitian yang dilakukan oleh Greenberg (1993) yang mendapatkan bahwa karyawan yang merasa diperlakukan secara tidak adil maka mereka akan mencari kesempatan untuk membalas apa yang dirasakan, dengan cara mereka sendiri, meskipun tindakan mereka itu tidak etis. Hasil penelitian ini dapat dijadikan dasar bagi penelitian selanjutnya.

Sedangkan implikasi praktis bagi manajer dan para praktisi di BMT antara lain: pertama, para menajer perlu memperhatikan faktor keadilan dalam mengambil keputusan yang terkait dengan pembagian dan pemerataan sumberdaya yang dimiliki karena akan berdampak pada etika kerja Islam bawahannya. Kalau karyawan merasa diperlakukan secara tidak adil dapat menimbulkan penurunan komitmen karyawan untuk menjujung tinggi etika yang Islam yang diyakini. Perlakuan yang tidak fair ini pada akhirnya juga akan berpengaruh terhadap produktifitas karyawan dalam organisasi tersebut.

Kedua, manajer BMT juga perlu memperhatikan prosedur dalam penentuan pembagian sumberdaya. Proses ini sangat peting, 
kalau karyawan selalu dilibatkan atau paling tidak memperoleh imformasi yang akurat tentang proses penentuan maka akan menimbulkan kesadaran bahwa berapapun jumlah yang mereka terima akan dirasakan adil karena proses penentuannya sudah adil. Dan sebaliknya, meskipun bagian yang mereka terima besar tetapi prosedur yang dilakukan dianggap kurang fair maka akan berpengaruh terhadap etika kerja Islam. Ketiga, manajer BMT juga perlu memperhatikan perlakukan mereka terhadap para bawahan. Hasil penelitian ini menunjukkan bahwa keadilan dalam proses interaksi sangat berpengaruh terhadap penggunaan etika kerja Islam. Sikap manajer yang memperlakukan bawahan secara hormat dan menghargai secara individu akan sangat berpengaruh terhadap eksistensi dan kontribusinya terhadap organisasi yang pada akhirnya akan berpengaruh pada komitmen karyawan dalam menerapkan etika kerja yang Islami dalam lingkungan kerjanya.

Dari hasil-hasil yang diperoleh pada penelitian ini, ada beberapa kelemahan yang perlu dibenahi untuk penelitian yang akan datang supaya mendapatkan hasil yang lebih baik. Adapun keterbatan dan saran adalah sebagai berikut: pertama, kuesioner hanya didistribusikan di BMT di Kabupaten Kudus saja, sehingga cakupan penelitian ini cukup sempit. Hal ini menyebabkan tingkat generalisasi hasil penelitian ini kurang. Penelitian lanjutan hendaknya mengambil sampel di tingkat yang lebih luas seperti di wilayah Jawa Tengah atau Jawa sehingga hasilnya bisa di generalisasi. Kedua, variabel yang dilibatkan dalam penelitian sedikit, hanya tiga dimensi keadilan organisasi dan Etika kerja Islam. Penelitian lanjutan hendaknya memasukkan variabel hasil kerja seperti kinerja, kepuasan kerja atau komitmen kerja, sehingga cakupan variabel lebih luas. Kelemahan yang terakhir, penelitian ini hanya menggunakan data kroseksional yaitu diambil pada satu saat saja, penelitian lanjutan lebih baik dilakukan secara longitudinal yaitu pengamatan jangka panjang sehingga akan menghasilkan kajian yang lebih komprehensif. 


\section{DAFTAR PUSTAKA}

Abeng, $\mathrm{T}$ "Business ethics in Islamic context: perspectives of a Muslim business leader" dalam Journal of Business Ethics Quarterly Vol. 7 No. 3, 1997.

Ali, A. "Scaling an Islamic work ethic" dalam Journal of Social Psychology, Vol. 5, 1988.

Colquitt, J. A., Greenberg, J. dan Zapata-Phelan, "What is Organizational Justice?. A historical overview". dalam Handbook of Organizational Justice, LEA Publisher, Mahwah. NJ, 2005.

J. A., Greenberg, J. dan Zapata-Phelan, "What is Organizational Justice?. A historical overview" Handbook of Organizational Justice. LEA Publisher, Mahwah. NJ, 2005.

Cropanzano, R. dan J. Greenberg. "Progress in organizational justice: tunneling through the maze dalam International Review of Industrial and Organizational Psychology, Vol. 12, 1997.

D. E. dan Gilliland, S. W. "The management of organizational justice" dalam Academy of Management Perspectives, Vol. 21, 2007.

Greenberg, J.. "Justice in the Workplace: Approaching Fairness in Human Resource Management" dalam R. Cropanzano (Eds.), The Social Side of Fairness:Interpersonal and Informational Classes of Organizational Justice. Hillsdale, NJ: Lawrence Erlbaum Associates, 1993.

Khalil dan Abu-Saad "Islamic work ethic among arab college students in Israel" dalam Cross Cultural Management: An International Journal Vol. 16 No. 4, 2009.

Leventhal, GS. "The distribution of rewards and resources in groups and organizations" dalam L. Berkowitz and 
E. Walster (Eds.), Advances in Experimental Social Psychology, Vol. 9, 1980.

Rizk, R. R. "Back to basics: an Islamic perspective on business and work ethics", dalam Social Responsibility Journal, Vol. 1, No. 2, 2008.

Schminke, M., Ambrose, M. dan Noel, T. "The effect of ethical frameworks on perceptions of organizational justice" dalam Academy of Management Journal, Vol. 40, No. 5, 1997.

Thibaut, J. dan Walker, L. "Procedural Justice: A Psychological Analysis" dalam Hillsdale, NJ: Lawrence Erlbaum Associates, 1975.

Tre Trevino, L. dan Weaver, G. "Organizational Justice and ethic program "follow-trough": influences on employees' harmful and helpful behavior" Journal of Business Ethics Quarterly, Vol. 11, No. 4, 2001.

Yousef, D. A. "Organisational commitment as a mediator of the relationship between Islamic work ethic and attitudes toward organisational change" dalam Journal of Human Relations, Vol. 53, No. 4, $2000 .$. 
Wahibur Rokhman

halaman ini bukan sengaja dikosongkan 